\title{
Analysis of Antioxidant Compounds and Hydroxymethylfurfural in Processing Tomato Cultivars
}

\author{
Lajos Helyes $^{1}$, Andrea Lugasi ${ }^{2}$, Zoltán Pék ${ }^{1,3}$, and Sára Brandt ${ }^{1}$
}

ADDITIONAL INDEX wORDs. lycopene, growing degree-day, polyphenols, ascorbic acid, total antioxidant status, Lycopersicon esculentum

SUMmARY. Tomato (Lycopersicon esculentum) fruit is an important source of antioxidants, which are important in the prevention of many cancer types and cardiovascular diseases. In ripe tomato fruit, one of the most significant antioxidant compounds is lycopene. In this study, effects of the cultivars and the environmental conditions on the lycopene content were investigated. Temperature effect was characterized by calculating growing degree-day (GDD). Relationships among lycopene, total polyphenols, organic acid, and total antioxidant status (TAS) were analyzed. A variation of more than $30 \%$ was found among the lycopene levels of five processing tomato cultivars. Lycopene content ranged from 79.7 to $155.0 \mathrm{mg} \cdot \mathrm{kg}^{-1}$ fresh weight. There was a significant difference between the lycopene concentrations of fruit harvested at two different dates. The values were higher at the second harvest, probably due to the cooler weather conditions preceding that harvest. Total polyphenols correlated strongly with TAS but the other antioxidants did not have any relationship to TAS. GDD were strongly and positively correlated with hydroxymethylfurfural content in fresh tomatoes.

$\mathrm{T}$ The nutrient value of tomato fruit is intimately connected with its composition in carbohydrates, organic acids, minerals, vitamins, and pigments (Helyes, 1999). In the last few years the consumption of tomatoes has played a great part in the prevention of many cancer types and cardiovascular diseases (Djuric and Powell, 2001; Levy et al., 1995; Micozzi et al., 1990; Takeoka et al., 2001). This protective effect is due to the antioxidant compounds in tomato fruit. These compounds are, among others, carotenoids, polyphenols, flavonoids, and ascorbic acid. The most essential carotenoid form is lycopene. Lycopene acts by quenching the singlet oxygen and scavenging peroxyl radicals, which cause the oxidative modification of lipids, proteins, low density lipoprotein (LDL) particles, and DNA (Oshima et al., 1996; Tapiero et al., 2004). This antioxidant activity is related to its acyclic molecular structure involving 11 conjugated double bonds. Lycopene has the ability to regulate intercellular communication and cell growth. For

This study was partially funded by grants from the Ministry of Education, Hungary (GAK/szokglak ALAP1-00140/2004 Project)

${ }^{1}$ Dept. of Horticulture and Technology, Szent István University, Páter K. út 1., H-2103 Gödöllö, Hungary.

${ }^{2}$ National Institute for Food Safety and Nutrition, Gyáli út 3/a H-1097 Budapest, Hungary.

${ }^{3}$ To whom reprint requests should be addressed; telephone: +36 28 522071; fax: +3628 410804; e-mail pek.zoltan@mkk.szie.hu that reason it may enhance inhibition of tumor cell growth (Bertram et al., 1991; Trosko and Chang, 2001). The biosynthesis of lycopene is under genetic control (Hanson et al., 2004). It is formed from phytoene during four desaturation steps (Harker and Hirschberg, 1998). The lycopene content of tomato fruit is influenced by the cultivar and also by cultural practices and environmental conditions. Lycopene forms more readily at lower temperatures, 16 to $26^{\circ} \mathrm{C}$ being the most favorable temperature range. Above $30{ }^{\circ} \mathrm{C}$ its biosynthesis is inhibited (Türk et al., 1994). According to Helyes et al. (2002) the lycopene content of tomato fruit cultivated in Hungary ranged from 39 to $171 \mathrm{mg} \cdot \mathrm{kg}^{-1}$. Tomato fruit is also rich in polyphenols, which amount to the largest part of the antioxidant capacity of the soluble phase. Thermal stress induces the accumulation of phenolic compounds like flavonoids and phenylpropanoids. At $35^{\circ} \mathrm{C}$, the polyphenol level is double that produced at $25^{\circ} \mathrm{C}$ (George et al., 2004). This phenomenon could be considered an acclimation mechanism of the plant against heat stress (Rivero et al., 2001).
Polyphenols similar to lycopene have antioxidant capacity, which repeatedly exceed the capacity of ascorbic acid. George et al. (2004) measured large variations among the polyphenol (104-400 $\mathrm{mg} \cdot \mathrm{kg}^{-1}$ ) and ascorbic acid (85-560 mg. $\mathrm{kg}^{-1}$ ) content of different tomato cultivars. Light exposure enhances ascorbic acid accumulation in tomato fruit (Dumas et al., 2003). Tomatoes grown in greenhouses have lower ascorbic acid content than those grown in open fields (Lopez-Andreu et al., 1986). The quality and the chemical compounds of tomato change during thermal processing. High temperature treatment can promote a browning in processed tomatoes. In processed products, both enzymatic and nonenzymatic reactions are responsible for the development of brown compounds. The Maillard reaction belongs to the last group. Its intermediate compound is hydroxymethylfurfural (HMF), which is harmful to human health. HMF can be found not only in processed tomato foods but also in fresh fruit. According to Cámara et al. (2003), HMF content is directly proportional to the lycopene content of the processed tomato products. The aim of our study was to establish the effect of temperature on lycopene content in five processing tomato cultivars. The relationship between TAS and antioxidant molecules such as lycopene, total polyphenols, and ascorbic acid was also analyzed.

\section{Materials and methods}

Plant materials. The experiment was conducted on the Experimental Farm of the Department of Horticultural Technologies at Szent István University, Gödöllö. Open-field experiments were conducted with five cultivars in 2001 ['Bonus' (Seminis Hungária Vetömag Kft., Budapest, Hungary), 'Early Fire' (United Genetics, Hollister, Calif.), 'Falcorosso' (Nunhems, Haelen, The Netherlands), and 'Nívó' and 'Korall' (Hungarian Vegetable Seed Co., Zöldségtermesztési Kutató Intézet, Kecskemét, Hungary)]; and one cultivar ('Early Fire') in 2002. The experimental design was

\begin{tabular}{llll}
\hline $\begin{array}{l}\text { Units } \\
\text { To convert U.S. to SI, } \\
\text { multiply by }\end{array}$ & U.S. unit & SI unit & $\begin{array}{l}\text { To convert SI to U.S., } \\
\text { multiply by }\end{array}$ \\
\hline 0.3048 & $\mathrm{ft}$ & $\mathrm{m}$ & 3.2808 \\
0.0929 & $\mathrm{ft}^{2}$ & $\mathrm{~m}^{2}$ & 10.7639 \\
1 & $\mathrm{ppm}$ & $\mathrm{mg} \cdot \mathrm{kg}^{-1}$ & 1 \\
$\left({ }^{\circ} \mathrm{F}-32\right) \div 1.8$ & ${ }^{\circ} \mathrm{F}$ & ${ }^{\circ} \mathrm{C}$ & $\left(1.8 \times{ }^{\circ} \mathrm{C}\right)+32$
\end{tabular}


a randomized block, with four replications for each cultivar. Seeds were sown on 5 Apr. 2001 in the greenhouse and transplanted on 11 May 2001. Seedlings were planted in twin rows $(0.4 \mathrm{~m})$ with $0.4-\mathrm{m}$ spacing inside the row and $1.4 \mathrm{~m}$ between adjacent twin rows, and individual plots were $80 \mathrm{~m}^{2}$. During the growing season, nutrition supply, irrigation, and plant protection followed recommendations for commercial tomato production in the region (Helyes and Varga, 1994). Fruit samples were picked randomly by hand from the middle section of the plants. The sampling section was $5 \mathrm{~m}$ in each plot. This procedure was carried out twice: on 22 Aug. and 5 Sept. 2001. 'Early Fire' processing tomato also was cultivated in 2002. The growing method was identical to that followed in 2001. Sowing in the greenhouse was conducted on 10 Apr. and field transplanting on 16 May in 2002. Fruit were sampled three times (30 July, 21 Aug., and 4 Sept.) in 2002.

MEASURement OF ENVIRONMENTAL PARAMETERs. Temperature and photosynthetically active radiation $(P A R)$ were measured six times per hour (hourly mean were recorded and daily mean were calculated), using a Skye DataHog micrometeorological instrument, placed at 2-m height (Skye Instruments Ltd, Llandrindrod Wells, U.K.) (Fig. 1). Reduced ceiling method with $10^{\circ} \mathrm{C}$ base and $32^{\circ} \mathrm{C}$ ceiling temperature was used to calculate GDD in case of lycopene and $10{ }^{\circ} \mathrm{C}$ base and $24^{\circ} \mathrm{C}$ ceiling temperature in case of HMF (Perry et al., 1997).

Chemical analysis. Four fruit from each of four repetitions were washed, cut, and mixed using homogenizer (PT 3100; Kinematica Inc., Newark, N.J.) and the juice samples were refrigerated at $-18{ }^{\circ} \mathrm{C}$ until analysis. Lycopene from homogenized tomato was extracted with $\mathrm{n}$-hexane-methanol-acetone $(2: 1: 1)$ mixture containing $0.05 \%$ butylated hydroxytoluene (BHT). Water-free sodium sulphate $\left(\mathrm{Na}_{2} \mathrm{SO}_{4}\right)$ was used to remove water traces from the upper part. Optical density of the hexane extract was measured spectrophotometrically at $502 \mathrm{~nm}$, compared with the hexane blank (Sadler et al., 1990) using a ultraviolet-visible spectrophotometry (UV-VIS) spectrophotometer (Lambda 3B; PerkinElmer Life and Analytical Sciences, Inc., Wellesley, Mass.). The concentration of lycopene was calculated using the specific extinction coefficient $\mathrm{E}_{\mathrm{lcm}} 1 \%$ 3150 (Merck and Co., Inc., 1989). Total polyphenols were determined using the Folin-Denis method according to the Association of Official Analytical Chemists (AOAC) official method of analysis 952.03 (AOAC, 1990). Ascorbic acid content was measured chromatographically using high performance liquid chromatography (Dong and Pace, 1996).

The determination of TAS was carried out using the Randox diagnostic kit (Randox Laboratories Ltd., Crumlin, U.K.) according to the procedure de- veloped by Miller et al., (1993). HMF was quantified using the colorimetric method based on the thiobarbituric acid color reaction measured at 443 nm (Guzmán et al., 1986).

STATISTICAL analysis. Two-way analysis of variance (ANOVA) was used and the means separated according to Student's test at $P=0.05$ to determine significant differences among cultivars, harvesting dates, and years. The correlation analysis was done by the linear regression-analysis module. All statistical analyses were performed using the Microsoft ${ }^{\circledR}$ Excel 2002
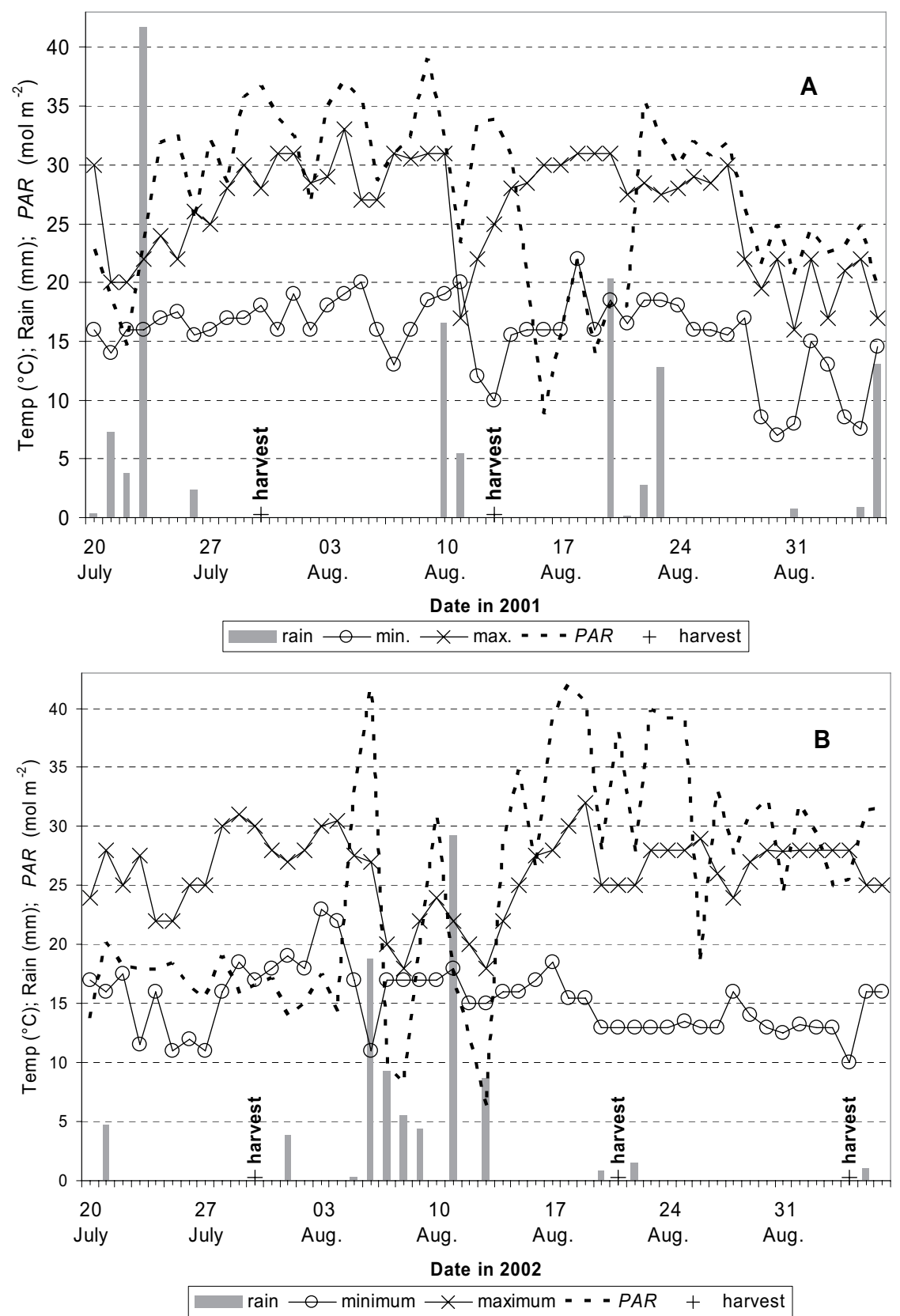

Fig. 1. Daily temperature (Temp), photosynthetically active radiation $(P A R)$, and rainfall (Rain) during tomato fruit development in (A) 2001 and (B) 2002; (1.8 $\left.\times{ }^{\circ} \mathrm{C}\right)+32={ }^{\circ} \mathrm{F} ; 1 \mathrm{~mm}=0.0394$ inch; $1 \mathrm{~m}^{2}=10.7639 \mathrm{ft}^{2}$. 
Analysis Toolpak (Microsoft Corp., Redmond, Wash.).

\section{Results and discussion}

There were significant differences in lycopene contents of the five processing tomato cultivars harvested in September, but not in August (Table 1). Lycopene content of the cultivars ranged from 79.7 to 155.0 $\mathrm{mg} \cdot \mathrm{kg}^{-1}$, 'Nívó' having the highest content $\left(155.0 \mathrm{mg} \cdot \mathrm{kg}^{-1}\right)$, and 'Early Fire' second with a very similar value (140.5 mg. $\mathrm{kg}^{-1}$ ). The lycopene content of 'Falcorosso' and 'Korall' differed significantly from that of 'Nívó' and 'Early Fire' at the second harvesting date. The lycopene content of fruit differed between the two harvest dates. The lycopene content of the fruit harvested on $22 \mathrm{Aug}$. ranged from 79.7 to $101.0 \mathrm{mg} \cdot \mathrm{kg}^{-1}$, whereas the lycopene concentrations of the fruit harvested on 5 Sept. ranged from 111.3 to 155.0 $\mathrm{mg} \cdot \mathrm{kg}^{-1}$ in $200 \mathrm{l}$ (Table $\mathrm{l}$ ). The amount of lycopene in the second harvest was generally higher than that in the first harvest. The average lycopene content of the samples picked on 5 Sept. was $45 \%$ higher than in samples harvested earlier. In the $10 \mathrm{~d}$ preceding the 22 Aug. harvest, there was more than 20 mm rainfall and the maximum temperature was over $30^{\circ} \mathrm{C}$ on five occasions (Fig. 1). These conditions probably inhibited lycopene production and could explain why the lycopene content was lower by $40.7 \mathrm{mg} \cdot \mathrm{kg}^{-1}$ than the average. On the other hand, the week preceding the second harvest was rainy and cold. During this week, the minimum temperature was $10^{\circ} \mathrm{C}$ on 5 of $7 \mathrm{~d}$ and the maximum values were hardly higher than $20{ }^{\circ} \mathrm{C}$. It is likely that the low temperatures activated the biosynthesis of lycopene. Each tomato plant was supplied with the same fertilizer and the same amount of water so the large difference in the lycopene content between the two harvests was probably caused by weather conditions.

Ascorbic acid level was highly variable, ranging from 161 to $447 \mathrm{mg} \cdot \mathrm{kg}^{-1}$. In the samples picked on 22 Aug. it was generally higher than in those picked on 5 Sept. (Table 1). Ascorbic acid content was inversely proportional to the lycopene level. The ascorbic acid content decreased by more than $50 \%$ at the second harvest date. Ascorbic acid is synthesized from glucose and its accumulation has been shown to increase under high solar radiation conditions (Dumas et al. 2003; Winsor and Adams, 1976) $10 \mathrm{~d}$ preceding the first harvest. As mentioned earlier, weather conditions before the second harvest were wet and cloudy.

Lycopene analysis was repeated in 2002 with cultivar Early Fire and data analysis showed no year by treatment interaction. We compared the average lycopene content in the harvests of 22 Aug., and 5 Sept. in 2001, with the average lycopene content in the harvests of 21 Aug. and 4 Sept. in 2002. We could not find any significant difference between the 2 years at $P=0.05$.

The last $10 \mathrm{~d}$ of the ripening phase may play a key role in the formation of lycopene. Lycopene accumulates mainly in the last period of ripening (Brandt et al., 2006). The average daily tem- perature during the $14 \mathrm{~d}$ before harvest (August) rose steadily from 17 to $26^{\circ} \mathrm{C}$ in both years, which can be considered roughly as the optimum temperature for tomato plants. The maximum temperature, however, exceeded six times in 2001 and twice in 2002 the critical value of $30{ }^{\circ} \mathrm{C}$. Temperature prior to the second harvest varied from 12 to 22 ${ }^{\circ} \mathrm{C}$ in 2001 and 19 to $21^{\circ} \mathrm{C}$ in 2002. Maximum temperature did not exceed $30{ }^{\circ} \mathrm{C}$ during this period. The cooler weather conditions may have caused the higher lycopene level of tomato fruit in the second harvest. For this reason, only the heat units accumulated during the $10 \mathrm{~d}$ preceding the harvest were used. There was significant negative correlation (significant at $P=0.001$ ) between GDD and lycopene content of fruit (Fig. 2).

Table 1. Lycopene and ascorbic acid content of five tomato cultivars at two harvest dates in 2001 (mean $\pm S D, n=4)$.

\begin{tabular}{lccllll}
\hline & \multicolumn{2}{c}{ Lycopene $\left(\mathbf{m g} \cdot \mathbf{k g}^{-1}\right)^{\mathrm{z}}$} & & \multicolumn{2}{c}{ Ascorbic acid $\left(\mathbf{m g} \cdot \mathbf{k g}^{-1}\right)^{\mathrm{z}}$} \\
\cline { 2 - 3 } \cline { 6 - 7 } Cultivars & 22 Aug. & $\mathbf{5 ~ S e p t . ~}$ & & 22 Aug. & 5 Sept. \\
\hline Early Fire & $101.0 \pm 20.9$ & $140.5 \pm 17.0 \mathrm{ab}$ & & $286.5 \pm 10.7 \mathrm{a}$ & $163.0 \pm 35.2$ \\
Bonus & $85.2 \pm 2.9$ & $127.0 \pm 27.9 \mathrm{ab}$ & & $334.0 \pm 60.0 \mathrm{ab}$ & $161.0 \pm 29.7$ \\
Falcorosso & $79.7 \pm 17.2$ & $111.3 \pm 28.3 \mathrm{~b}$ & & $415.3 \pm 49.6 \mathrm{~b}$ & $162.3 \pm 24.8$ \\
Korall & $81.0 \pm 14.8$ & $113.0 \pm 7.0 \mathrm{~b}$ & & $446.5 \pm 105.5 \mathrm{~b}$ & $191.0 \pm 28.9$ \\
Nívó & $97.0 \pm 18.3$ & $155.0 \pm 14.0 \mathrm{a}$ & & $441.5 \pm 28.2 \mathrm{~b}$ & $192.5 \pm 54.5$ \\
Average & 88.7 & 129.4 & & 348.8 & 174.0 \\
\hline
\end{tabular}

${ }^{2} \mathrm{mg} \cdot \mathrm{kg}^{-1}=1 \mathrm{ppm}$.

'Data in the same column bearing the same letter are not significantly different at the $5 \%$ level (tested by Student's test).

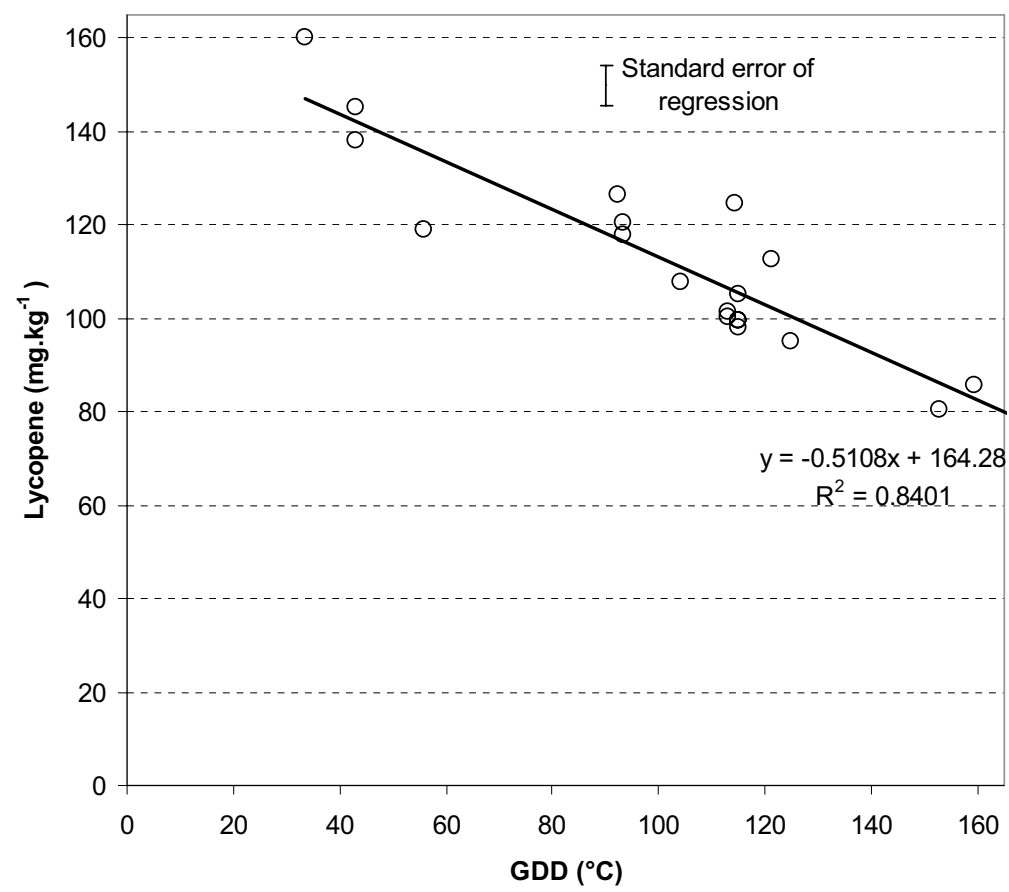

Fig. 2. Correlation between lycopene content of 'Early Fire' tomato fruit and growing degree-day (GDD) in 2001-02 $(n=20)$. The vertical bar represents the standard error of the regression. $1 \mathrm{mg} \cdot \mathrm{kg}^{-1}=1 \mathrm{ppm} ;\left(1.8 \times{ }^{\circ} \mathrm{C}\right)+32={ }^{\circ} \mathrm{F}$. 


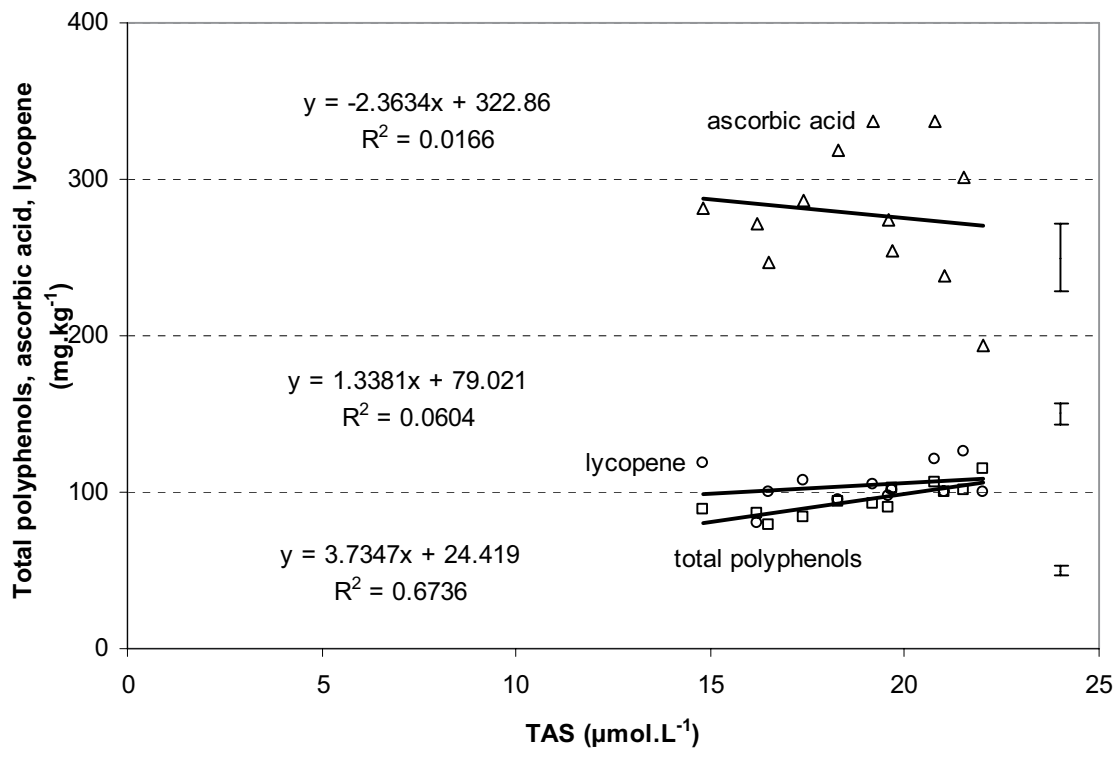

Fig. 3. Correlation between antioxidants (total polyphenols, ascorbic acid, lycopene) and total antioxidant status (TAS) of tomato fruit in $2002(n=12)$. The vertical bars represent the $\mathrm{SE}$ of regressions; $1 \mathrm{mg} \cdot \mathrm{kg}^{-1}=1 \mathrm{ppm}, 1 \mathrm{~L}=0.2642$ gal.

Table 2. Lycopene and hydroxymethylfurfural (HMF) content of 'Early Fire' tomato at three harvest dates in $2002($ mean $\pm S D, n=4) .^{2}$

\begin{tabular}{lcccc}
\hline & & 30 July & 21 Aug. & 4 Sept. \\
\hline Lycopene $\left(\mathrm{mg} \cdot \mathrm{kg}^{-1}\right)^{\mathrm{y}}$ & Average & $102.2 \pm 18.9$ & $100.5 \pm 3.1$ & $110.4 \pm 13.6$ \\
$\mathrm{HMF}\left(\mathrm{mg} \cdot \mathrm{kg}^{-1}\right)^{\mathrm{y}}$ & Average & $12.8 \pm 1.5$ & $14.3 \pm 2.6$ & $11.3 \pm 1.7$ \\
\hline
\end{tabular}

${ }^{2}$ Differences among harvest dates were nonsignificant.

y $\mathrm{mg} \cdot \mathrm{kg}^{-1}=1 \mathrm{ppm}$.

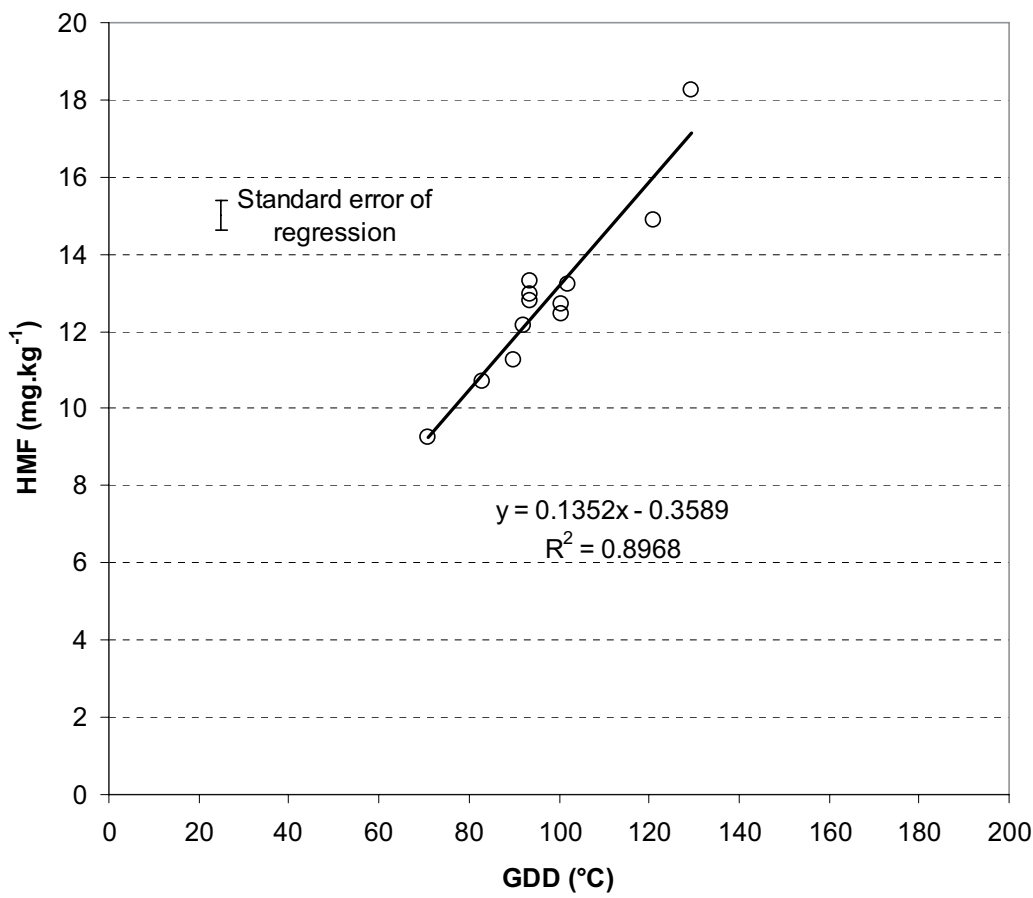

Fig. 4. Correlation between hydroxymethylfurfural (HMF) content of tomato fruit and growing degree-day (GDD) in $2002(n=12)$. The vertical bar represents the SE of regression; $1 \mathrm{mg} \cdot \mathrm{kg}^{-1}=1 \mathrm{ppm} ;\left(1.8 \times{ }^{\circ} \mathrm{C}\right)+32={ }^{\circ} \mathrm{F}$.
Astrong correlation $(\mathrm{r}=0.82)$ was obtained between the total polyphenols level and TAS (Fig. 3) but lycopene ( $\mathrm{r}$ $=0.24)$ and ascorbic acid $(\mathrm{r}=0.13)$ did not correlate with TAS. The average total polyphenol contents of three harvesting dates ranged from 78.6 to $115.4 \mathrm{mg} \cdot \mathrm{kg}^{-1}$.

According to Cámara et al. (2003), HMF content is in direct proportion to the lycopene content of the processed tomato. HMF can form not only during industrial processing, but also is synthesized during different physiological processes (photosynthesis, transpiration) in the plant. The aim of our experiments was to determine the HMF level in fresh tomato fruit and the relationship between GDD and HMF. The differences between the lycopene and HMF content of the three harvests were not significantly different (Table 2). Correlation analysis suggested a strong positive relation $(\mathrm{r}$ $=0.95$ ) between GDD and HMF (Fig. 4 ) in fresh tomatoes.

Lycopene content is determined fundamentally by the genetic nature of cultivars, but is also strongly affected by environmental factors. The lycopene content is greatly reduced above $30^{\circ} \mathrm{C}$. A close negative relation was found between GDD and lycopene content and a strong positive connection between GDD and HMF in fresh tomatoes. The antioxidant content of fruit of the processing tomato studied depended mostly on environmental conditions (mainly temperature) and genetic factors.

\section{Literature cited}

Association of Official Analytical Chemists. 1990. Official method of analysis, 15th ed. Assn. Offic. Anal. Chemists, Arlington, Va.

Bertram, J.S., A. Pung, M. Cheerley, T.J. Kappock, L.R. Wilkins, and R.V. Cooney. 1991. Diverse carotenoids protect against chemically induced neoplastic transformation. Carcinogenesis 12:671-678.

Brandt, S., Z. Pék, É. Barna, A. Lugasi, and L. Helyes 2006. Lycopene content and colour of ripening tomatoes as affected by environmental conditions. J. Sci. Food Agr. 86:568-572.

Cámara, M., M.C. Matallana, M.C. Sánchez-Mata, R. Lillo Ayué, and E. Labra. 2003. Lycopene and hydroxymethylfurfural (HMF) evaluation in tomato products. Acta Hort. 613:365-371. 
Djuric, Z. and L.C. Powell. 2001. Antioxidant capacity of lycopene-containing foods. Intl. J. Food Sci. Nutr. 52:143-149.

Dong, M.W. and J.L. Pace. 1996. A rapid HPLC method for multivitamin analysis. Liquid Chromatography-Chromatography $14: 794-803$.

Dumas, Y., M. Dadomo, G. Di Lucca, and P. Grolier. 2003. Effects of environmental factors and agricultural techniques on antioxidant content of tomatoes. J. Sci. Food Agr. 83:369-382.

George, B., Ch. Kaur, D.S. Khurdiya, and H.C. Kapoor. 2004. Antioxidants in tomato (Lycopersicum esculentum) as a function of genotype. Food Chem. 84:45-51.

Guzmán, G.A., J. Corbalán, J. Laencina, M. Nunez, and G. Guzmán MartinezValls. 1986. HMF, Indicodor de modificaciones indeseables en cremogenades de albaricoque. Alimentación, equipos y technológia 6:73-76.

Hanson, P.M., R.Y. Yang, J. Wu, J.T. Chen, D. Ledesma, S.C.S. Tsou, and T.C. Lee. 2004. Variation for antioxidant activity and antioxidants in tomato. J. Amer. Soc. Hort. Sci. 129:704-711.

Harker, M. and J. Hirschberg. 1998. Molecular biology of carotenoid biosynthesis in photosynthetic organisms. Methods Enzymology 297:244-263.

Helyes, L. 1999. A paradicsom és termesztése. Syca Szakkönyvszolgálat, Budapest, Hungary.

Helyes, L., A. Lugasi, S. Brandt, G. Varga, J. Hóvári, and É. Barna. 2002. A paradicsom likopin tartalmát befolyásoló tényezök értékelése, elemzése. Kertgazdaság 34:1-8.
Helyes, L. and G. Varga. 1994. Irrigation demand of tomato according to the results of three decades. Acta Hort. 376:323-328.

Levy, J., E. Bizin, B. Feloman, Y. Giat, A. Minister, M. Danilenko, and Y. Sharoni. 1995. Lycopene is more potent inhibitor of human cancer cell proliferation than either $\alpha$-carotene or $\beta$-carotene. Nutr. Cancer 24:257-266.

Lopez-Andreu, F.J., A. Lamela, R.M. Esterban, and J.G. Collando, 1986. Evolution of quality parameters in the maturation stage of tomato fruits. Acta Hort. 191:387-394.

Merck and Co., Inc. 1989. Merck index, llth ed. Merck and Co., Rahway, N.J.

Micozzi, M.S., G.R. Becheer, P.R. Taylor, and F. Kahchik. 1990. Carotenoid analyses of selected raw and cooked foods associated with a lower risk for cancer. J. Natl. Cancer Inst. 82:282-288.

Miller, N.J., C. Rice-Evans, M.J. Davies, V. Gopinathan, and A. Milner. 1993. A novel method for measuring antioxidant capacity and its application to monitoring the antioxidant status in premature neonates. Clinical Sci. 84:407-412.

Oshima, S., F. Ojima, H. Sakamoto, Y. Ishigura, and J. Terao. 1996. Supplementation with carotenoids inhibits singlet oxygen-mediated oxidation of human plasma low-density lipoprotein. J. Agr. Food Chem. 44:2306-2309.

Perry, K.B., Y. Wu, D.C. Sanders, T.J. Garrett, D.R. Decoteau, R.T. Nagata, R.J. Dufault, K.D. Batal, D.M. Granberry, and W.J. Mclaurin, 1997. Heat units to predict tomato harvest in the southeast USA. Agr. For. Meteorol. 84:249-254.
Rivero, R.M., J.M. Ruiz, P.C. Garcia, L.R. López-Lefebre, E. Sánchez, and L. Romero. 2001. Resistance to cold and heat stress: accumulation of phenol compounds in tomato and watermelon plants. Plant Sci. 160:315-321.

Sadler, G., J. Davies, and D. Dezman. 1990. Rapid extraction of lycopene and $\beta$-carotene from reconstituted tomato paste and pink grapefruit homogenates. J. Food Sci. 55:1460-1461.

Takeoka, G.R., L. Dao, S. Flessa, D.M.W. Gillesp, T. Jewell, B. Huebner, D. Bertow, and S.E. Ebeller. 2001. Processing effects on lycopene content and antioxidant activity of tomatoes. J. Agr. Food Chem. 49:3713-3717.

Tapiero, H., D.M. Townsend, and K.D. Tew. 2004. The role of carotenoids in the prevention of human pathologies. Biomedicine Pharmacotherapy 58:100-110.

Trosko, J.E. and C.C. Chang. 2001. Mechanism of up-regulated gap junctional intercellular communication during chemoprevention and chemotherapy of cancer. Mutation Res.-Fundamental Mol. Mutagenesis 480:219-229.

Türk, R., V. Seniz, N. Ozdemir, and M.A. Suzen. 1994. Changes in the chlorophyll carotenoid and lycopene accumulation in tomatoes in relation to temperature. Acta Hort. 368:856-862.

Winsor, G.W. and P. Adams. 1976. Changes in the composition and quality of tomato fruits throughout the season. Res. Rpt. Glasshouse Crops Res. Inst. 134-142. 